\title{
Reflective Learning as a Model of Character Education for the Teacher Candidate in the Industrial Revolution 4.0
}

\author{
Albert I Ketut Deni Wijaya* \\ Faculty of Teacher Training and Education \\ STKIP Widya Yuwana \\ Madiun, Indonesia \\ alber.deni@yahoo.com
}

\author{
Antonius Virdei Eresto Gaudiawan \\ Faculty of Teacher Training and Education \\ STKIP Widya Yuwana \\ Madiun, Indonesia
}

\begin{abstract}
This study aimed to explore how reflective learning helps in character education in the era of the industrial revolution 4.0 for teacher candidates. This research used descriptive qualitative research. Data collection techniques were carried out using the FGD (Focus Group Discussion) method. This qualitative research was analyzed by inductive method. The place of research is at STKIP Widya Yuwana in Madiun, at the bachelor program of Catholic Religious Education. The research respondents are teacher candidates. The finding of the research shows that there are five types of reflective learning; reflective learning which helps them acknowledge their duty as a teacher, helps them to prepare themselves as a teacher, strengthens their motivation to be a teacher, helps their personal formation, and it is not useful if always used. Meanwhile, in general, the respondents give 4 or 5 marks on the impact of the reflective learning in motivating their call as a teacher. It can be seen that $43 \%$ respondents give 4 marks and $29 \%$ respondents give 5 marks. Based on the research results, it can be concluded that reflective learning is able to help to strengthen the character of teacher candidates and to motivate them to become teachers.
\end{abstract}

Keywords - reflective learning; character building; industrial revolution 4.0

\section{INTRODUCTION}

The term industrial revolution was firstly introduced by Prof. Klaus Martin Schwab. He is a Germany technician and economist, who is also the founder and the Executive Chairman of World Economic Forum. Schwab in The Fourth Industrial Revolution stated that this world has experienced four revolution stages [1]. The first is The Industrial Revolution 1.0 that happened in the eighteen centuries through the invention of the steam engine. This revolution affected the ability to make mass production. The second is the Industrial Revolution 2.0 that happened in the $19^{\text {th }}-20^{\text {th }}$ century through the invention of electricity. It made the falling of production costs. The third is the Industrial Revolution 3.0 that happened in 1970 through the invention of the computer. The fourth is the Industrial Revolution 4.0 that happened approximately in 2010 through the invention of artificial intelligence and internet as the backbone of movement and connectivity of human and engine.

The Industrial Revolution 4.0 impacts the human life. It changes the way people think, live and connect each other. We encounter disruption in the field of economy, social and politic. According to Prasetyo, changes in the field of economy can be seen through the improvement in the online taxi and "ojek" [2]. In the society, the internet makes unlimited interaction possible. In the politic, the internet makes people easier to accumulate many groups that bring some ideological platform.

Behind those improvements, there are bad effects. Nowadays, we must aware of the hoax that spread through digital information media. Technology is used nowadays to spread the hoax. In the midst of this industrial revolution, it is important to think on the character formation of the teacher candidate. Reflective learning is a form of education formation that can be used for teacher candidates. There are a lot of researches on reflective learning. Those researches show that reflective learning gives good impacts for the students in understanding the material and improving their character [3]-[6].

This research has two purposes. The first is to understand the impact of reflective learning for the character development of teacher candidates, especially to counter the industrial revolution 4.0. And the second is to understand how big reflective learning motivates their call as teacher candidates.

\section{RESEARCH METHOD}

This research used descriptive qualitative method. By using this research method, we hoped to grasp qualitative information with much detail and nuance that is more than only number or frequency. Focus Group Discussion (FGD) was used to collect the data. In the FGD, we used open question to understand the deepness of the information and we did it in unstructured ways.

This research took place in the STKIP Widya Yuwana (Widya Yuwana College for Education) on the bachelor program of Catholic Religious Education. It is held in this program because there are many religious teacher candidates. They are the main subject of this research. This qualitative research uses inductive method to analyze the data. All of the information is gathered from the respondents. The analysis process was done together with the collecting data process by using many reflection techniques to understand the deep and firm data. The data were compared to see its connection with the purpose of this research. 


\section{RESULTS AND DISCUSSION}

\section{A. Reflective Learning}

Reflective learning is an educational process in which students interact with the material with the help of the teacher. In this process, the student becomes the centre of the learning process to help them achieve awareness of knowledge and values with their full responsibility. This model will equip them not only with knowledge, but also capability to think and act according to their conscience and the will to give empathy to others (Suparno, 2015). Reflective learning can be done in 5 steps, such as to see the context, to have experience, to do reflection, to act and to evaluate.

\section{1) Understanding the Context}

In this step, human experience becomes the foundation of reflective learning. It means that reflective learning happens in a such context that begin from student's real experience (Saptono, 2012).

\section{2) Presents Experience}

Saptono (2012) stated that the student's experience consists of cognitive and affective aspects. There are two kinds of experiences: direct and indirect experiences. Direct experience is reality that is really faced by the students. Indirect experience is other's real experience or constructed experience.

\section{3) Reflection}

Reflection itself is an effort to grasp the material fully. The material can be some topics, ideas, proposal and even spontaneous reaction. Through the reflection, students try to find deeper meaning and consequence of every experience. In this step, the teacher has to prepare some reflective question. And this is not a simple task [7]

\section{4) Action}

Subagya (2010) stated that action is the inner growth that is based on reflection on his or her experience and its manifestation. This action consists of two things: a) inner choice, a choice that is based on a believe that his or her decision is right and will make him or her better; b) understanding choice, a choice that arise after the stated intentions are thought by which students will be motivated to do consistent action in accordance with his or her priority. If they find positive meaning, that action will be an advantage habit.

\section{5) Evaluation}

It is a step backward to see the improvement that has been reached in the education process. Assessment is the way to evaluate. The focus of the assessment is not only in the academic field, but also the student improvement as a whole whether as a personal or social people [8]. Subagya hoped that the assessment is done in an effective, holistic and routine way [3]. Evaluation then becomes means to improve students' habit and behaviour.

Hartana in his writing explained five excellences of reflective learning [5]. First, students have real experience to actively contribute in the learning process. Second, students have more capability and skill to reflect on his or her experience during the study by which he or she finds the values that exist in every material and process of learning. Third, it is a chance of the teachers to optimize their function as motivator on the study. Fifth, teachers will have an inward connection with their students by understanding and recognizing the student's context of life.

Further, Hartana stated three weaknesses of reflective method [5]. First, the teacher has to give more time to prepare the syllabi, lesson plan, reflective question and response student's reflection. Second, the teacher has to understand and acknowledge every single student's context in order to treat student correctly and uniquely. Third, the teacher has to regularly update his or her knowledge and awareness on the concrete situation in order to guide the students to do the concrete reflection and action.

\section{B. Character Education for The Teacher Candidates}

Teaching is a profession. The profession itself should be understood as a work that needs special skill and can't be done by lay people. It means that the teacher has to have professionalism in doing his or her job. The professionalism of a teacher can be seen from three dimensions, such as having an expertise in his work, responsibility and have a sense of colleague [9].

Being a teacher is also a divine calling from God [9]. It means that a teacher has to be ready to serve his or her students whole-heartedly. This attitude can't be thought out of God's care of human beings. Being a teacher that serves whole-heartedly is not a simple thing. There is so much barriers that has to be coped. First, he or she has to serve every stratum of society. Second, he or she must teach not only by his or her words, but also with his attitude, act and behaviour. Third, he or she must accentuate the students than the material.

Nowadays, the teacher does not only teach in school. The teacher's role is broader. A teacher has to be an educator, mentor, researcher, persona, connector, reformer and developer [9]. From those images, a teacher is not enough to be clever and skilful. A teacher has to have excellent character. That is why character education is important in the formation of teacher candidates.

There are some definitions about character. Widiyanti, cited from The Centre of Language of Indonesian Department of Education, formulated character as "innate, heart, personality, behaviour, conduct, temperament, nature". From those description, people that have a character means having good personality, behaviour and temperament [10]. Zubaedi described the character as identity, personality and temperament that exist in a human being [11].

Zubaedi stated that character is constructed by three parts. Those three parts have correlation each other's [11]. They are moral knowing, feeling of knowing and moral behaviour. It means that character consists of three aspects: knowledge, feeling and action. They cannot be separated and complete each other. Habituation is needed to grow those characters and those need long process. The habituation should be in three scopes such as thinking, feeling and action.

\section{The Industrial Revolution 4.0 Era}

Science and technology in the industrial revolution era 4.0 develop vastly and give big impact to the human being. People can access many services through the digital technology. The services become faster, more efficient, and 
reach vast area. The cost of life becomes easier and cheaper. In spite of the improvement from the industrial revolution 4.0 , it also gives negative impact. Ghufron stated that it causes the decrease of the human's role that is changed by the automatic machines [12].

To counter that situation, a new movement is needed. A movement that is planned by Indonesian government is a new literacy to strengthen and even change the old literacy [12]. The new literacy movement consists of literacy of the digital world, technology and humanity.

Digital literacy is needed to improve our ability to read, analyze and use information from the big data. Data literacy is needed by the stakeholders to improve their capability to process and analyze the big data. It will improve public services and the economy.

Technological literacy is needed to give knowledge on how machines work and how to use them. It will make people have the ability to utilize digital technology. Capability to utilize digital technology is useful in processing data and information.

Human literacy is conducted toward the improvement of people capability to communicate and master design science. It must be mastered because it will show people's soft-skill or individual capability to collaborate, adapt and be wise in this flood of information.

The reflective learning is a way to counter the industrial revolution 4.0. Collins, in Saptono, stated that through reflective learning, student is invited to familiarize himself or herself to do investigation, thematization and problematization before they do something [7]. It is important because we are in the midst of the flood of information nowadays. This condition makes students receive so much information, but they lack of capability to comprehend the consequence and the meaning for their life. Through the reflective learning, we hope that students improve their capability to understand the information deeply, to get the meaning and to realize the consequence of their own improvement. It will make them more care toward their neighbour, social environment and the physical environment.

\section{The Research Result on Reflective Learning for Teacher} Candidates

1) Impact of the reflective learning toward the character development of teacher candidates

There are five types answer in this matter. The first is that reflective learning helps them acknowledge their duty as a teacher. The second, reflective learning help them to prepare themselves as a teacher. The third, it strengthens their motivation to be a teacher. The fourth, it helps their personal formation. And the fifth, it is not useful if always used.

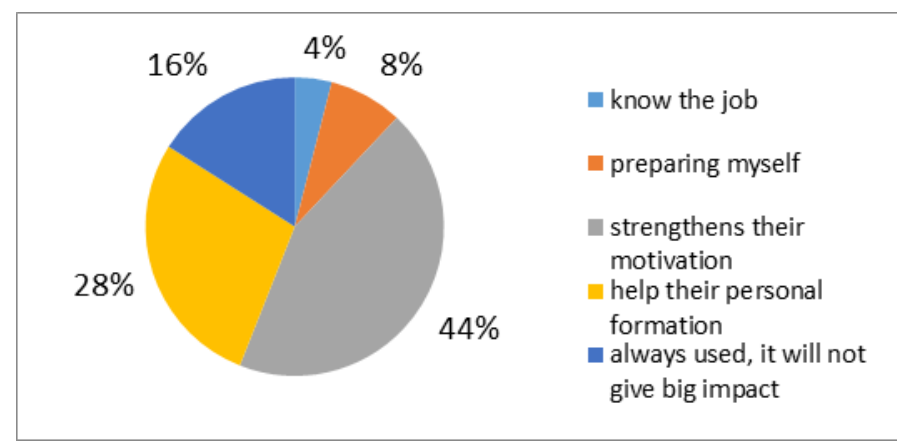

Impact of the reflective learning.

From those five answers, there are three dominant answers that reflective learning which strengthens their motivation, helps their personal formation and if always used, it will not give big impact. The first, reflective learning strengthens their motivation. The respondents realize that doing reflection at the end of the class help them to get the meaning of their activity. It makes them have a guidance to do their task and prepare themselves for their duty ahead. It enables them to reconstruct their personality and attitude.

The second, reflective learning helps their personal formation. The respondents realize that the teacher has not the duty only to teach, but also to teach through their speech, deeds and attitude. Teachers must be the role model for their students. To be a role model they not only have to be skilful in teaching, but also have to do what they teach in their daily life. Moreover, teachers have to serve their students. It makes them realize that to be a good and wise teacher they have to master the way to evaluate themselves. Reflective learning is a way to evaluate themselves. Through reflection, they can understand their strengths and weaknesses and how to improve it.

The third, doing reflective learning regularly will not give big impact. The respondents see the bad impact of the reflective learning process. If this mode of reflection is seen solely for the mark of the students and occurred frequently, it will fail. It makes the students do reflection again and again to make the professor feel happy.

It can be concluded that reflective learning gives a big impact for the personality formation of the teacher candidates. The most positive impact is it helps them to motivate themselves and shape themselves.

\section{2) The Impact of Reflective Learning to Motivate the Teacher Candidates}

The result of the research shows that reflective learning has big impact in motivating their call as a teacher. It can be seen from the respondent's answers when they are asked to mark from 1-5 toward the reflective learning.

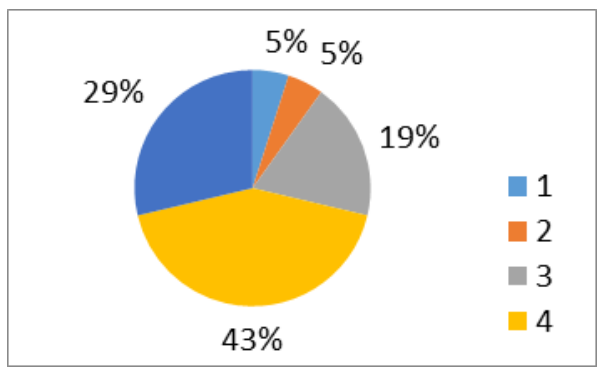

Fig. 1. Impact to Motivate the Teacher Candidates. 
In general, the respondents give 4 or 5 marks on the impact of the reflective learning in motivating their call as a teacher. It can be seen that $43 \%$ respondents give 4 marks and $29 \%$ respondents give 5 marks. Their marks cannot be separated from their experience. They feel that through reflective learning their motivation becomes purer. They feel that reflective learning helps them to prepare themselves to be an excellent teacher.

\section{CONCLUSION}

It can be concluded that reflective learning will be a big help for the teacher candidates to strengthen their character and motivation. The reflective learning can be used as an effective way in educating teacher candidates in this industrial revolution 4.0 era.

\section{REFERENCES}

[1] K. Schwab, "The fourth industrial revolution. New York: Crown Business.” 2017.

[2] B. Prasetyo and U. Trisyanti, "Revolusi Industri 4.0 dan Tantangan Perubahan Sosial," IPTEK J. Proc. Ser., no. 5, pp. 22 27, 2018.

[3] H. S. P. Putri Stefani Dwiana, Veronika Ines Nugraheni, "Analisis Hasil Refleksi Dalam Penerapan Pendekatan Paradigma Pedagogi Reflektif Pada Pembelajaran Matematika di Kelas X6 SMA Kolose De Brito Yogyakarta," in Seminar Nasional Matematika dan Terapannya, 2016, pp. 297-305.

[4] F. G. Putra, "Pengaruh Model Pembelajaran Reflektif dengan Pendekatan Matematika Realistik Bernuansa Keislaman terhadap Kemampuan Komunikasi Matematis," Al-Jabar J. Pendidik. Mat., vol. 7, no. 2, pp. 203-210, 2016.

[5] A. Hartana, P. Setyosari, and D. Kuswandi, "Penerapan Strategi Pembelajaran Paradigma Pedagogi Ignatian (Reflektif) Terhadap Peningkatan Hasil Belajar Dan Motivasi Berprestasi Belajar Ilmu Pengetahuan Alam (Ipa) Siswa Kelas V Sekolah Dasar," $J$. Pendidik. Teor. Penelitian, dan Pengemb., vol. 1, no. 4, pp. 765779, 2016.

[6] M. Marnita, "Model Pembelajaran Reflektif Learning Untuk Meningkatkan Keterampilan Proses Sains Dan Penguasaan Konsep Siswa Pokok Bahasan Kalor Dan Perpindahannya Di Kelas VII Mtsn," J. Pendidik. Almuslim, vol. 5, no. 1, 2017. S. Saptono, "PEMBELAJARAN REFLEKTIF: UPAYA
[8]

P. Wahana, "Mengenal Pendekatan Paradigma Pedagogi Reflektif dalam Pendidikan untuk Membangun Manusia yang Cerdas dan Humanis," DIDAKTIKA, vol. 5, no. 1, 2016.

[9] S. Wahyuni, "Profesi guru adalah panggilan Ilahi," J. Antusias, vol. 3, no. 5, pp. 147-160, 2014.

[10] S. A. Widiyanti, "Pengaruh Pendidikan Karakter Dengan Pendekatan Paradigma Pedagogi Reflektif dan Motivasi Belajar terhadap Kepribadian Siswa dalam Pendidikan Agama Katolik di SMP Katolik Se-Kota Madiun." UNS (Sebelas Maret University), 2012.

[11] D. P. K. Zubaedi, "Konsepsi dan Aplikasinya dalam Lembaga Pendidikan," Jakarta: Kencana, 2011.

[12] G. Ghufron, "Revolusi Industri 4.0: Tantangan, Peluang, dan Solusi bagi Dunia Pendidikan," in Seminar Nasional dan Diskusi Panel Multidisiplin Hasil Penelitian dan Pengabdian Kepada Masyarakat 2018, 2018, vol. 1, no. 1. MEMBUMIKAN HERMENEUTIK DALAM PRAKTIK PENDIDIKAN," Satya Widya, vol. 28, no. 1, pp. 73-82, 2012. 